\title{
Comparison of peripartum metabolic status and postpartum health of Holstein and Montbéliarde-sired crossbred dairy cows
}

\author{
L. G. D. Mendonça, ${ }^{*}$ C. C. Abade, ${ }^{*}$ E. M. da Silva, ${ }^{*}$ N. B. Litherland, $\dagger$ L. B. Hansen, $\dagger$ W. P. Hansen, $\dagger$ \\ and R. C. Chebel ${ }^{\star 1}$ \\ ${ }^{*}$ Department of Veterinary Population Medicine, and \\ †Department of Animal Sciences, University of Minnesota, Saint Paul 55108
}

\begin{abstract}
Objectives of the current experiment were to evaluate plasma concentrations of metabolites and haptoglobin peripartum, uterine health and involution, and follicle growth and resumption of cyclicity of Holstein (HO) and Montbéliarde-sired crossbred cows. Cows (52 $\mathrm{HO}$ and 52 crossbred) were enrolled in the study $45 \mathrm{~d}$ before expected calving date. Cows had body weight and body condition score recorded on d $-45,-14,0$, 1,28 , and 56 relative to calving. Dry matter intake was calculated for a subgroup of cows $(25 \mathrm{HO}$ and 38 crossbred) from $6 \mathrm{wk}$ before to $6 \mathrm{wk}$ after calving. Blood was sampled weekly from $\mathrm{d}-14$ to 56 relative to calving for determination of glucose, nonesterified fatty acid, and $\beta$-hydroxybutyrate concentrations; from $\mathrm{d}-7$ to 21 relative to calving for determination of haptoglobin concentration; and from d 14 to 56 postpartum for determination of progesterone concentration. Cows were examined at calving and on $\mathrm{d} 4,7,10$, and 14 postpartum for diagnosis of postparturient diseases, on d 24 postpartum for diagnosis of purulent vaginal discharge, and on d 42 postpartum for diagnosis of subclinical endometritis. Uteri and ovaries were examined by ultrasonography every $3 \mathrm{~d}$ from d 14 to 41 postpartum. Milk yield and composition were measured monthly and yield of milk, fat, protein, and energy-corrected milk were recorded for the first $90 \mathrm{~d}$ postpartum. Body weight was not different between Holstein and crossbred cows, but HO cows had reduced body condition score compared with crossbred cows. Even though DMI from $6 \mathrm{wk}$ before to $6 \mathrm{wk}$ after calving tended to be greater for $\mathrm{HO}$ cows $(16.8 \pm 0.7$ vs. $15.3 \pm 0.5 \mathrm{~kg} / \mathrm{d})$, $\mathrm{HO}$ cows tended to have more pronounced decline in dry matter intake, expressed in percentage of body weight from d -15 to 0 relative to calving. Energy-corrected milk and nonesterified fatty acid and $\beta$-hydroxybutyrate concentrations were not different between breeds. No
\end{abstract}

Received June 19, 2013.

Accepted October 10, 2013.

${ }^{1}$ Corresponding author: chebe002@umn.edu differences were observed in incidence of retained fetal membranes, metritis, and subclinical endometritis, but $\mathrm{HO}$ cows tended to be more likely to have pyrexia from d 0 to 15 postpartum (50.0 vs. $31.4 \%$ ) and to have greater incidence of purulent vaginal discharge (44.2 vs. $26.5 \%)$ than crossbred cows. Holstein cows were more likely to have at least 1 uterine disorder postpartum than crossbred cows (63.5 vs. $36.7 \%$ ). No differences between breeds were observed in uterine involution. Holstein cows had larger subordinate follicles (10.1 \pm 0.4 vs. $8.9 \pm 0.5)$ and a greater number of class III follicles $(1.6 \pm 0.1$ vs. $1.2 \pm 0.1)$ than crossbred cows. Furthermore, the first corpus luteum postpartum of HO cows was diagnosed at a slower rate compared with crossbred cows. Crossbred cows had improved uterine health compared with $\mathrm{HO}$ cows and this may have been a consequence of heterosis and (or) breed complementarity and less pronounced decrease in DMI during the last days of gestation.

Key words: crossbreeding, metabolic status, postpartum health, dairy cow

\section{INTRODUCTION}

Crossbreeding is used with the intent of improving phenotypic characteristics (e.g., health, fertility, longevity, and milk components) through the benefits of heterosis, which reduces the likelihood of inbreeding depression. Inbreeding is the probability of 2 alleles at any locus to be identical by descent (Falconer and Mackay, 1996) and is more likely to occur in purebred individuals because purebred individuals have greater relationship among them. Inbreeding depression is mostly characterized by reduced productivity (Charlesworth and Willis, 2009). Young and Seykora (1996) demonstrated an increased relationship among individuals of the Holstein (HO) breed, the most predominant breed in the United States dairy herd (NAHMS, 2007), which could result in increased inbreeding and negatively affect the United States dairy industry. Therefore, crossbreeding of dairy breeds could be an alternative to increase the genetic diversity in the United States dairy herd and reduce inbreeding depression. 
Productive parameters of crossbred and purebred dairy cows have been compared in an attempt to characterize the advantages of heterosis with regard to milk composition and yield of milk fat and protein (Wriedt, 1930; Cole and Johansson, 1948). Experiments have demonstrated that crossbred cows $[\mathrm{HO} \times$ Jersey and Jersey $\times \mathrm{HO}$ ] were less likely to have metritis than purebred HO cows (Olson et al., 2011). Furthermore, Montbéliarde (MO) cows had reduced SCS (Koç, 2011) and MO-sired crossbred cows were less likely to be removed from the herd (Heins et al., 2012) than purebred HO cows. Data regarding metabolic parameters, acute-phase protein, uterine involution, and follicle growth and resumption of cyclicity postpartum between purebred $\mathrm{HO}$ and MO-sired crossbred cows are not as abundant.

The transition period ( 3 wk before to 3 wk after parturition) of lactating dairy cows is marked by physiological and metabolic changes that affect immune function and increase susceptibility to postpartum diseases (Goff and Horst, 1997). Dairy cows that developed metritis postpartum had reduced DMI prepartum (Hammon et al., 2006; Huzzey et al., 2007) and compromised neutrophil function on the day of calving (Hammon et al., 2006) compared with healthy cows. Insufficient DMI to meet energy demands results in negative energy balance and increased plasma NEFA concentrations, an indicator of fat mobilization (Grummer et al., 2004). The capacity of complete FA oxidation in the liver can be indirectly measured by the concentration of plasma BHBA, which is a product of incomplete oxidation of NEFA (Palmquist, 1972). Elevated concentrations of these metabolites (NEFA and BHBA) are associated with increased incidence of diseases peripartum and compromised productive and reproductive performances of dairy cows (LeBlanc, 2010).

Our hypotheses were that purebred HO cows would have greater incidence of health disorders and delayed uterine involution compared with MO-sired crossbred cows. The objectives of the current experiment were to evaluate concentrations of metabolites and haptoglobin peripartum, uterine health and involution, and follicle growth and resumption of cyclicity of purebred $\mathrm{HO}$ and MO-sired crossbred cows during the peripartum period.

\section{MATERIALS AND METHODS}

\section{Cows, Breeds, Enrollment Period, Dry Period}

The experiment was conducted at the University of Minnesota St. Paul dairy. Fifty-two purebred HO (19 nulliparous and 33 parous) and $52 \mathrm{MO}$-sired crossbred (6 nulliparous and 46 parous) cows were used. Cows were expected to calve from November 2009 to Febru- ary 2010 and in October and November 2010. In the manuscript, cows that had their first calving during the experiment will be referred to as primiparous and cows that had their second or greater calving during the experiment will be referred to as multiparous. Cows were enrolled in the study $45 \mathrm{~d}$ before expected calving date. The enrollment period was from October 2009 to January 2010 (first season of parturition) and during the month of September 2010 (second season of parturition). The mean $( \pm \mathrm{SEM})$ and median length of the dry period were $51.8( \pm 1.9)$ and $49 \mathrm{~d}$, respectively.

\section{$B W$ and BCS}

Data regarding BW and BCS were collected on $\mathrm{d}-45$ $\pm 5,-14 \pm 3,0-1,28 \pm 3$, and $56 \pm 3$ relative to calving. During the prepartum period, cows were weighed in the a.m. before feeding and during the postpartum period cows were weighed immediately after the a.m. milking. Body condition score was assessed by 1 person using the visual technique on a scale of 1 (severe under conditioning) to 5 (severe over conditioning) with 0.25 increment (Ferguson et al., 1994).

\section{Diets and Calculation of DMI}

Cows were fed a TMR once daily and water was available ad libitum. The TMR offered during the dry period consisted of wheat straw, corn silage, alfalfa hay, ground dry corn, soybean meal (first season of parturition), and a protein mix. The lactating cow TMR consisted of corn silage, alfalfa hay, ground dry corn, soybean meal (first season of parturition), whole cottonseed (second season of parturition), and a protein mix. The composition of the TMR is described in Table 1.

Individual DMI from $\mathrm{d}-45$ to 42 relative to calving of a subgroup of multiparous cows ( $\mathrm{HO}=25$ and crossbred $=38$ ) was determined. These cows had individual feeding bins and amount of feed offered and orts were weighed daily and daily DMI was calculated based on DM content of the ration offered and orts. For statistical analysis, daily DMI and weekly averages of DMI were used. Furthermore, to estimate the DMI in the last $15 \mathrm{~d}$ of gestation, expressed as percentage of BW, individual daily DMI was divided by the individual BW on $\mathrm{d}-14$ relative to calving.

\section{Productive Parameters}

Cows were milked twice daily. The dairy was enrolled in a regular milk recording DHIA program. Data regarding production, milk composition, and SCC were collected monthly in the first 90 DIM. First, second, 
Table 1. Composition of TMR (\% of DM, unless otherwise noted) offered to dry and lactating dairy cows during the first and second season of parturition

\begin{tabular}{|c|c|c|c|c|}
\hline \multirow[b]{2}{*}{ Component } & \multicolumn{2}{|c|}{ First season } & \multicolumn{2}{|c|}{ Second season } \\
\hline & $\begin{array}{l}\text { Dry } \\
\text { cow }\end{array}$ & $\begin{array}{c}\text { Lactating } \\
\text { cow }\end{array}$ & $\begin{array}{l}\text { Dry } \\
\text { cow }\end{array}$ & $\begin{array}{l}\text { Lactating } \\
\text { cow }\end{array}$ \\
\hline DM, \% & 54.3 & 55.6 & 61.5 & 64.0 \\
\hline $\mathrm{NE}_{\mathrm{L}}, \mathrm{Mcal} / \mathrm{kg}$ & 1.51 & 1.75 & 1.47 & 1.66 \\
\hline $\mathrm{CP}$ & 13.2 & 17.8 & 17.0 & 16.6 \\
\hline RUP, $\%$ of CP & 23.9 & 43.1 & 20.5 & 38.9 \\
\hline RDP, $\%$ of $\mathrm{CP}$ & 76.1 & 56.9 & 79.5 & 61.1 \\
\hline $\mathrm{ADF}$ & 26.0 & 18.3 & 28.2 & 22.2 \\
\hline $\mathrm{NDF}$ & 39.8 & 29.6 & 41.9 & 31.6 \\
\hline Ether extract & 2.0 & 3.7 & 1.9 & 4.0 \\
\hline Ash & 8.2 & 8.7 & 8.9 & 7.4 \\
\hline Calcium & 0.71 & 0.87 & 0.81 & 0.80 \\
\hline Phosphorus & 0.26 & 0.43 & 0.41 & 0.47 \\
\hline Magnesium & 0.30 & 0.33 & 0.39 & 0.32 \\
\hline Potassium & 1.65 & 1.46 & 1.47 & 1.43 \\
\hline Sulfur & 0.26 & 0.27 & 0.35 & 0.27 \\
\hline Sodium & 0.04 & 0.42 & 0.13 & 0.46 \\
\hline Chlorine & 0.34 & 0.41 & 0.83 & 0.49 \\
\hline
\end{tabular}

and third tests were limited to tests that occurred at 5 to 34,35 to 64 , and 65 to 94 DIM, respectively. Energycorrected milk was calculated according to the formula (Tyrrell and Reid, 1965)

$$
\begin{gathered}
\operatorname{ECM}(\mathrm{kg})=(0.327 \times \text { milk yield }) \\
+(12.95 \times \text { fat yield })+(7.2 \times \text { protein yield }) .
\end{gathered}
$$

\section{Physical Exams and Uterine Health}

Because the objective of the current experiment was to evaluate metabolic parameters and health of $\mathrm{HO}$ and MO-sired crossbred cows associated with parturition, cows were examined at enrollment to determine eligibility. Cows diagnosed with digestive disorders, reproductive tract disorders, respiratory tract disorders, or lameness (lameness score $>2 ; 1=$ normal and $5=$ severely lame) were deemed not eligible to be enrolled in the experiment. Cows were monitored daily and cows that presented decreased appetite, depression, or dehydration were examined by a veterinarian.

All cows were examined on d $0,4,7,10$, and 14 relative to calving for diagnosis of retained fetal membranes (RFM) and metritis. Rectal temperature was measured daily from d 0 to 15 relative to calving. Retained fetal membrane was characterized as the failure of detachment of the fetal membranes within $12 \mathrm{~h}$ postpartum. Cows with rectal temperature $>39.5^{\circ} \mathrm{C}$ were considered to have pyrexia. Puerperal metritis was characterized by the presence of fever and a red/brown watery fetid uterine discharge (LeBlanc, 2010).

Cows were examined by vaginoscopy on d 24 postpartum for determination of purulent vaginal discharge.
The visual inspection of the external os of the cervix was performed with the aid of a flashlight and cows in which pus composed $>50 \%$ of the exudate were considered to have purulent vaginal discharge. Subclinical endometritis was diagnosed on d $42 \pm 3$ postpartum by cytological examination of endometrial samples collected using a cytobrush (Cytobrush Plus; CooperSurgical Inc., Trumball, CT) from the previously pregnant uterine horn. The cytobrush was rolled onto a clean glass slide, which was stained with modified WrightGiemsa stain (Protocol-Hema3; Biochemical Sciences Inc., Swedesboro, NJ). Slides were evaluated at $400 \times$ magnification 3 times by 1 examiner who was blinded to the breed of the cows. A minimum of 100 cells were counted at each reading and subclinical endometritis was determined by $>10 \%$ of total cells classified as PMNL (Kasimanickam et al., 2004).

\section{Blood Sample Collection and Analyses}

Blood was sampled weekly from d -14 to 56 relative to calving from the coccygeal vein/artery immediately before feeding while cows were resting. Needles used were $0.64 \mathrm{~mm}$ wide (22 gauge) and $25.4 \mathrm{~mm}$ long to minimize stress during sample collection. Blood samples were collected from the coccygeal vein/artery into evacuated tubes containing K2 EDTA (Becton Dickinson Vacutainer Systems, Franklin Lakes, NJ). Tubes were placed on ice until centrifugation for plasma separation $\left(1,200 \times g\right.$ for $15 \mathrm{~min}$ at $\left.4^{\circ} \mathrm{C}\right)$. Plasma was aliquoted into microcentrifuge tubes and stored at $-32^{\circ} \mathrm{C}$ until analysis.

Plasma NEFA was quantified using a colorimetric assay (Wako Chemicals USA, Richmond, VA; Ballou 
et al., 2009). $\beta$-Hydroxybutyrate concentration was determined enzymatically (Ranbut; Randox Laboratories Ltd., Crumlin, UK; Ballou et al., 2009). Glucose concentration was determined by enzymatic reaction (Stanbio Laboratory, Boerne, TX). Haptoglobin concentrations were measured by a colorimetric procedure as described by Hulbert et al. (2011).

A plate reader (SpectraMax 340; Molecular Devices LLC, Sunnyvale, CA) was used to measure the absorbance for the colorimetric and enzymatic assays. Control serum (Randox Control Sera; Randox Laboratories Ltd.) was used for the NEFA, BHBA, and glucose assays. The intraassay coefficients of variation for the assays were $5.5 \%$ for NEFA, $8.8 \%$ for BHBA, $4.0 \%$ for glucose, and $3.9 \%$ for haptoglobin. The interassay coefficients of variation for the assays were $10.1 \%$ for NEFA, $10.8 \%$ for BHBA, $5.1 \%$ for glucose, and $9.1 \%$ for haptoglobin, respectively.

Progesterone concentration was determined by a solid-phase RIA kit (Coat-a-Count; Siemens Medical Solutions Diagnostics, Los Angeles, CA) and the intra- and interassay coefficients of variation were 9.3 and $12.3 \%$, respectively. Cows that had a sample with progesterone concentration $<1 \mathrm{ng} / \mathrm{mL}$, followed by a sample with progesterone concentration $\geq 1 \mathrm{ng} / \mathrm{mL}$, and then a sample with progesterone concentration $<1 \mathrm{ng} / \mathrm{mL}$ were considered to have had a short luteal phase.

\section{Ultrasound Evaluation of Uterus and Ovaries}

In a subgroup of cows $[\mathrm{HO}=45$ (19 primiparous and 26 multiparous) and crossbred $=41$ (6 primiparous and 35 multiparous)], ultrasound examinations of the genital tract was performed at 3-d intervals from d 14 to 41 postpartum using an Aloka SSD 500 ultrasound system (Hitachi Aloka Medical Ltd., Tokyo, Japan) equipped with a $5-\mathrm{MHz}$ rectal probe to determine uterine involution, evaluate ovarian structures, and assess resumption of cyclicity. Uterine involution was determined by monitoring changes in the diameter of previously pregnant and nonpregnant uterine horns. The previously pregnant uterine horn was identified at one of the clinical examinations performed from d 0 to 14 postpartum by rectal palpation as being the horn with larger diameter. The uterine horns were scanned immediately anterior to the external uterine bifurcation. Cross-sectional diameters of the uterine horns were recorded, and the standardized measure of estimated volume (V) was calculated by the formula

$$
\mathrm{V}=\left\{4 / 3 \times \pi \times[(\mathrm{Dv} / 2 \times \mathrm{Dh} / 2) / 2]^{3}\right\},
$$

where $\mathrm{Dv}$ and $\mathrm{Dh}$ are the vertical and horizontal diameters, respectively, of the uterine horn.
Ovaries were scanned to determine the number and size of follicles greater than $5 \mathrm{~mm}$ in diameter and the volume of the corpus luteum (CL). Follicles were classified as class II ( 5 to $9 \mathrm{~mm}$ ) and class III $(\geq 10 \mathrm{~mm})$ and CL volume was calculated by the following formula:

$$
\begin{aligned}
& \Sigma\left(\left\{4 / 3 \times \pi \times\left[\left(\mathrm{d}_{\mathrm{a}} / 2+\mathrm{d}_{\mathrm{b}} / 2\right) / 2\right]^{3}\right\}\right. \\
& \left.-\left\{4 / 3 \times \pi \times\left[\left(\mathrm{c}_{\mathrm{a}} / 2+\mathrm{c}_{\mathrm{b}} / 2\right) / 2\right]^{3}\right\}\right),
\end{aligned}
$$

where $d_{a, b}$ and $c_{a, b}$ are orthogonal luteal and cavity dimensions, respectively, for the nth CL.

\section{Statistical Analysis}

The experiment was prospective observational. A sample size of 50 experimental units per treatment (HO vs. MO-sired crossbred) was expected to provide enough replicates to detect a difference of $0.115 \mathrm{mmol} / \mathrm{L}(\mathrm{SD}=$ $0.290 \mathrm{mmol} / \mathrm{L}$ ) in NEFA concentration between treatments $(\alpha=0.05 ; \beta=0.20 ; 1$-tailed test). Furthermore, this sample size $(\mathrm{n}=50 /$ treatment $)$ was expected to provide enough replicates to detect a difference of 0.210 $\mathrm{mmol} / \mathrm{L}(\mathrm{SD}=0.520 \mathrm{mmol} / \mathrm{L})$ in BHBA concentration ( $\alpha=0.05 ; \beta=0.20 ; 1$-tailed test).

Data were analyzed statistically by using SAS (version 9.2, SAS/STAT; SAS Institute Inc., Cary, NC). Continuous data measured repeatedly were analyzed by ANOVA for repeated measures using PROC MIXED of SAS. Covariance structure used [unstructured, compound symmetry, and autoregressive(1)] was chosen based on the Akaike information criterion. Dichotomous outcomes were analyzed by logistic regression using PROC LOGISTIC of SAS. Models used for the statistical analysis included breed (HO vs. MO-sired crossbred), parity (primiparous vs. multiparous), season of parturition (first vs. second), and the interactions between breed and parity. For analysis of repeated measurements, day relative to calving and the interaction between breed and day relative to calving were included in the model.

The Cox regression proportional hazard model was used to evaluate the association between breed and the interval from calving to detection of first CL or detection of progesterone concentration $\geq 1 \mathrm{ng} / \mathrm{mL}$ using PROC PHREG of SAS. The model included breed (HO vs. MO-sired crossbred), parity (primiparous vs. multiparous), season of parturition (first vs. second), and the interaction between breed and parity. Statistical significance was defined as $P \leq 0.05$ and statistical tendencies as $0.05<P \leq 0.10$.

\section{RESULTS}

Three cows were excluded from the experiment because of uterine prolapse $(\mathrm{n}=1$, crossbred cow $)$, be- 
cause of unresponsiveness to treatment for milk fever $(\mathrm{n}=1$, crossbred cow), and because of teat injury ( $\mathrm{n}$ $=1, \mathrm{HO}$ cow).

\section{$B W$ and $B C S$}

No association $(P=0.41)$ was observed between breed and $\mathrm{BW}$ from $\mathrm{d}-45$ to 56 relative to calving but the interaction between breed and day relative to calving was associated with $\mathrm{BW}(P=0.04$; Figure $1 \mathrm{~A})$. Holstein cows had lesser $(P<0.01)$ BCS than crossbred cows from $\mathrm{d}-45$ to 56 relative to calving (Figure $1 \mathrm{~B}$ ).

\section{DMI and Glucose, NEFA, and BHBA Concentrations}

Among the multiparous cows that had individual DMI measured, BW of $\mathrm{HO}$ and crossbred cows were $725.32 \pm 19.32$ and $745.63 \pm 15.67 \mathrm{~kg}$, respectively. Holstein cows tended $(P=0.08)$ to have greater DMI than crossbred cows from 6 wk before to 6 wk after calving (Figure 2A). Breed $(P=0.10)$ and the interaction between breed and day relative to calving $(P=0.10)$ tended to be associated with daily DMI, expressed as percentage of $\mathrm{BW}$ from $\mathrm{d}-15$ to 0 relative to calving (Figure 2B).
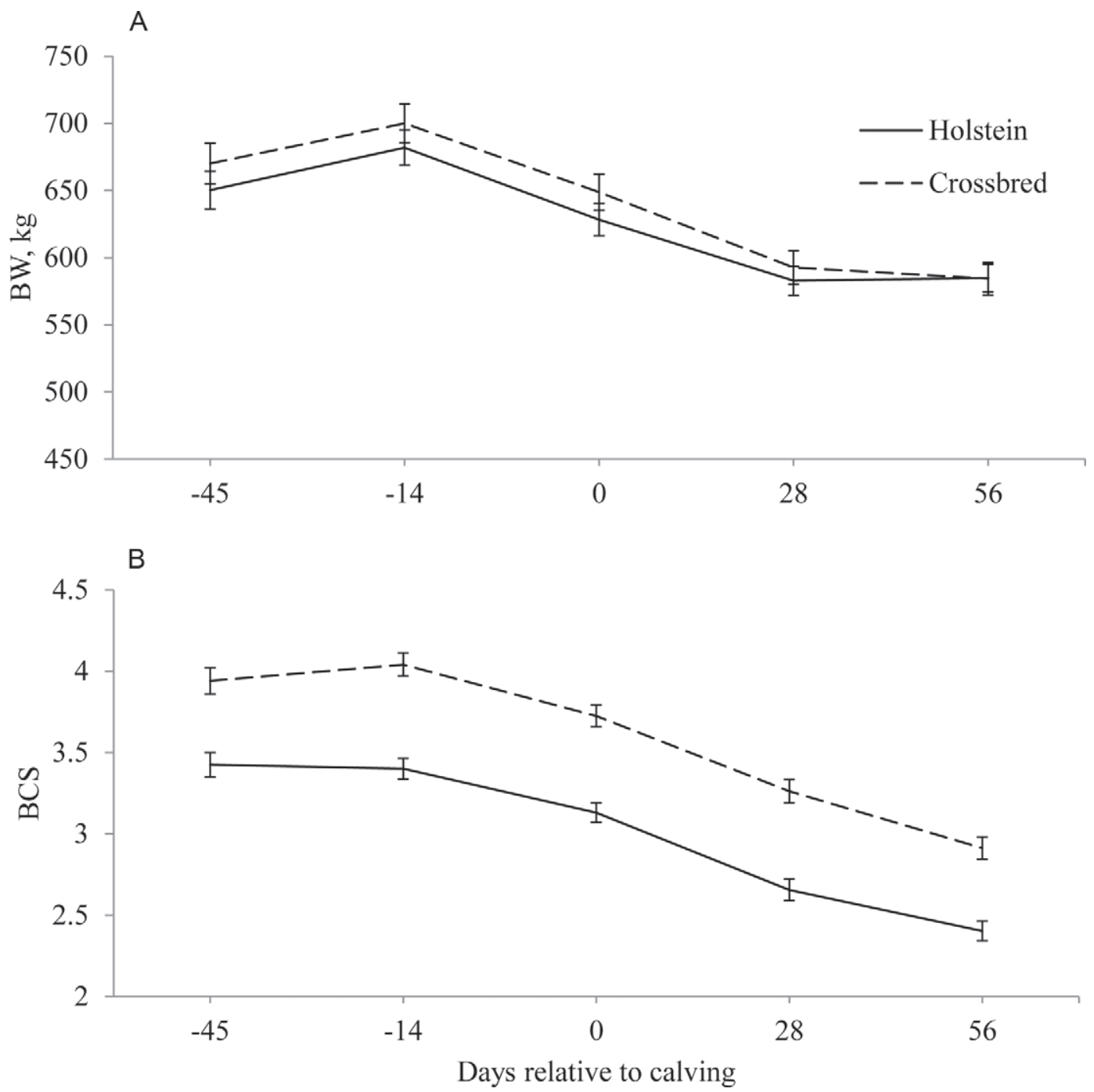

Figure 1. (A) Association between breed and BW from -45 to 56 d relative to calving. Breed was not associated with $\mathrm{BW}(P=0.41)$, but day relative to calving $(P<0.01)$ and the interaction between breed and day relative to calving $(P=0.04)$ were associated with BW. Such an interaction was observed because BW of Holstein cows was not different $(P=0.44)$ between 28 and $56 \mathrm{~d}$ relative to calving, but $\mathrm{BW}$ of Montbéliarde (MO)-sired crossbred cows $28 \mathrm{~d}$ after calving was greater $(P<0.01)$ than BW of MO-sired cows $56 \mathrm{~d}$ after calving. (B) Association between breed and BCS of Holstein and MO-sired crossbred cows. Holstein cows had reduced BCS $(P<0.01)$ compared with MO-sired crossbred cows throughout the experiment. Day relative to calving affected $(P<0.01)$ BCS, but the interaction between breed and day relative to calving was not associated with BCS $(P=0.26)$. Error bars represent SEM. 
Glucose concentration from d -14 to 56 relative to calving was not different $(P=0.54)$ between breeds $(77.0 \pm 0.8 \mathrm{mg} / \mathrm{dL})$, but the interaction between breed and day relative to calving was associated with glucose concentration $(P<0.01$; Figure $3 \mathrm{~A})$. Breed was not associated $(P=0.56)$ with NEFA concentration from d -14 to 56 relative to calving (Figure $3 \mathrm{~B}$ ). No association $(P=0.95)$ was observed between breed and BHBA concentration from $\mathrm{d}-14$ to 56 relative to calving (Figure 3C). The interaction between breed and day relative to calving, however, was associated with BHBA concentration $(P<0.01$; Figure $3 \mathrm{C})$.

\section{Postpartum Health Parameters and Haptoglobin}

Breed was not associated with incidence of stillbirth $(P=0.68)$, dystocia $(P=0.68)$, twin births $(P=$ $0.54)$, RFM $(P=0.82)$, or metritis $(P=0.11$; Table $2)$. Holstein cows tended $(P=0.07)$ to be more likely to have pyrexia (Table 2 ) and had greater daily rectal temperature $(P=0.02)$ from d 0 to 15 postpartum than crossbred cows $\left(39.1 \pm 0.1\right.$ vs. $\left.38.8 \pm 0.1^{\circ} \mathrm{C}\right)$. Inclusion of metritis as a covariate in the models to evaluate incidence of pyrexia and rectal temperature resulted in breed not being associated with incidence of pyrexia $(P=0.28)$ or rectal temperature $(P=0.16)$. Cows diagnosed with metritis were more likely to have pyrexia (100.0 vs. $35.5 \%$; $P=0.02$ ) and had greater rectal temperature from d 0 to 15 postpartum $(39.3 \pm$ 0.1 vs. $\left.38.9 \pm 0.1^{\circ} \mathrm{C} ; P<0.01\right)$ than nonmetritic cows.

Holstein cows tended $(P=0.07)$ to be more likely to have purulent vaginal discharge than crossbred cows. Breed was not associated with incidence of subclinical endometritis $(P=0.12$; Table 2$)$. Among cows diagnosed with subclinical endometritis, breed was associated $(P<0.01)$ with percentage of PMNL in the uterine cytology (crossbred $=18.4 \pm 2.9$ and $\mathrm{HO}=11.8 \pm$ $2.5 \%$ of total cells classified as PMNL). There was no difference $(P=0.33)$ between breeds in percentage of PMNL in the uterine cytology $(3.3 \pm 0.1 \%$ of total cells classified as PMNL) among cows without subclinical endometritis.

Combining the results of all uterine diseases (RFM, metritis, vaginal purulent discharge, and subclinical endometritis), HO cows were $(P<0.01)$ more likely to have at least 1 uterine disease compared with crossbred cows (Table 2$)$. Breed $(P=0.40)$, however, was not associated with haptoglobin concentration from $\mathrm{d}-7$ to 21 relative to calving (Figure 4).

\section{Uterine Involution}

Breed $(P=0.74)$ was not associated with volume of the previous pregnant horn (Figure 5). The inter- action between breed and parity was associated $(P=$ 0.01 ) with the mean volume of the previously pregnant uterine horn because among $\mathrm{HO}$ cows, parity was not associated with the volume of the previously pregnant uterine horn $(P=0.55)$. Multiparous crossbred cows, however, had $(P<0.01)$ greater uterine volume than primiparous crossbred cows $(13,306 \pm 918.3$ vs. 10,178 $\left.\pm 1,220.2 \mathrm{~mm}^{3}\right)$. Breed was not associated with the volume of the previously nonpregnant uterine horn from $\mathrm{d}$ 14 to 41 postpartum $(P=0.15$; Figure 5$)$.

\section{Postpartum Ovarian Activity and Progesterone Concentration}

Breed was not associated $(P=0.85)$ with the diameter of the largest follicle. The diameter of the subordinate follicle was greater $(P=0.03)$ for $\mathrm{HO}$ cows compared with crossbred cows (Figure 6). The number of class II follicles was not different between breeds $(P=0.17$; Figure 7A). Holstein cows, however, had a greater number of follicles class III than crossbred cows $(P<0.01 ;$ Figure 7B $)$.

Progesterone concentration did not differ between HO and crossbred cows $(P=0.24$; Figure 8$)$. Breed was not associated $(P=0.36)$ with the speed at which cows were detected to have progesterone concentration $\geq 1 \mathrm{ng} / \mathrm{mL}$ [adjusted hazard ratio $=1.24 ; 95 \%$ CI $=$ $0.79,1.93)$. The mean and median intervals from calving to detection of progesterone concentration $\geq 1 \mathrm{ng} /$ $\mathrm{mL}$ were $34.6 \pm 1.3$ and $28 \mathrm{~d}$, respectively. Holstein cows were more likely $(P=0.03)$ to have a short luteal phase compared with crossbred cows (adjusted odds ratio $=3.00 ; 95 \% \mathrm{CI}=1.01,8.00)$.

Among cows that ovulated, CL volume was not different $(P=0.97)$ between breeds $\left(4,861 \pm 188 \mathrm{~mm}^{3}\right)$. Diagnosis of the first CL after calving occurred faster $(P=0.03)$ in crossbred cows (referent) than $\mathrm{HO}$ cows (adjusted hazard ratio $=1.81 ; 95 \% \mathrm{CI}=1.07,3.08)$. The mean and median intervals from calving to detection of the first CL for crossbred cows were $28.4 \pm 1.4$ and $27 \mathrm{~d}$, respectively, and for HO cows were $30.2 \pm 1.6$ and $27 \mathrm{~d}$, respectively.

\section{Milk Production}

There was no association between breed and ECM yield $(P=0.72$; Table 3$)$ but milk yield during the first 90 DIM was greater for HO cows than crossbred cows $(P=0.05$; Table 3$)$. A tendency $(P=0.10)$ existed for the interaction between breed and parity to be associated with milk yield because milk yield of primiparous HO $(41.4 \pm 2.8 \mathrm{~kg} / \mathrm{d})$ and crossbred $(35.0 \pm 3.6 \mathrm{~kg} / \mathrm{d})$ cows was different $(P=0.05)$, but no differences $(P=$ 
A

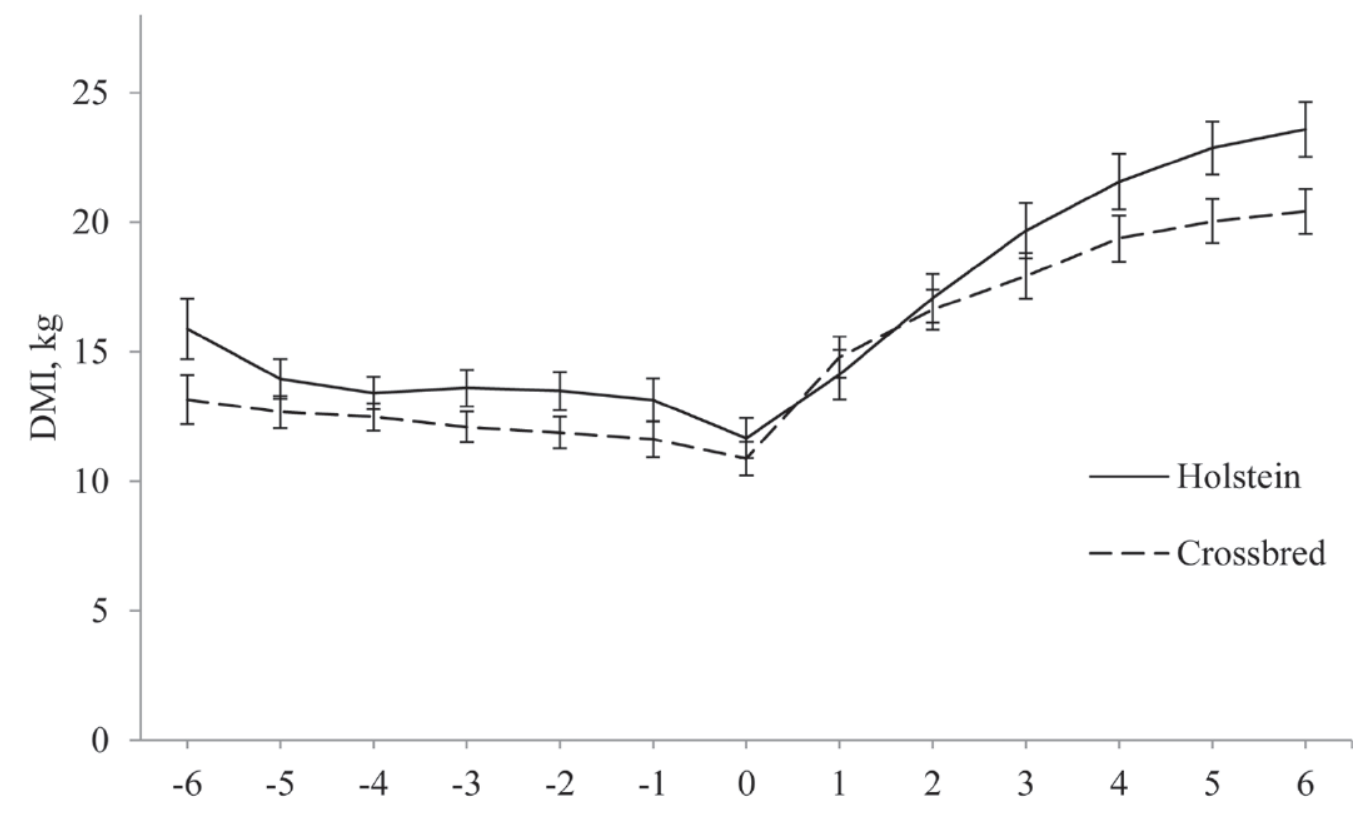

Weeks relative to calving

B

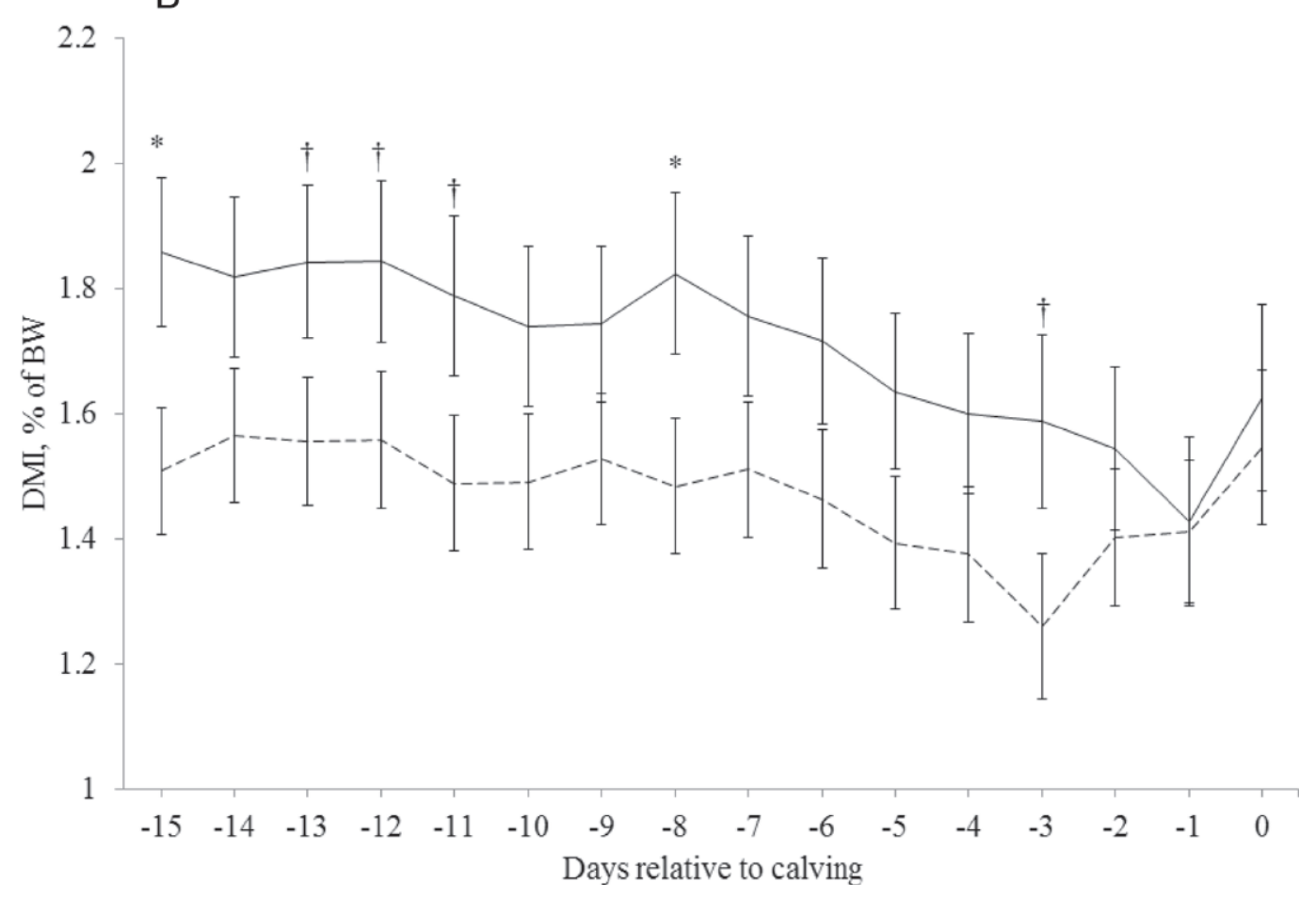

Figure 2. (A) Dry matter intake of a subgroup of multiparous Holstein $(\mathrm{n}=25)$ and Montbéliarde $(\mathrm{MO})$-sired crossbred $(\mathrm{n}=38)$ cows from wk 6 before calving to wk 6 after calving. Holstein $(\mathrm{HO})$ cows tended $(P=0.08)$ to have greater DMI than MO-sired crossbred cows. Week relative to calving was associated with DMI $(P<0.01)$, but the interaction between breed and week relative to calving was not associated with DMI $(P=0.29)$. (B) Association between breed and DMI from $15 \mathrm{~d}$ before calving to calving expressed in percentage of BW on $\mathrm{d} 14$ before calving (DMI expressed as percentage of BW). Mean ( \pm SEM) weights on d 14 before calving were $725.32 \pm 19.32$ and $745.63 \pm 15.67 \mathrm{~kg}$ for HO and MO-sired crossbred cows, respectively. A tendency $(P=0.10)$ existed for HO cows to have greater DMI (expressed as percentage of BW) than MO-sired cows. Day relative to calving was associated with DMI $(P<0.01)$, expressed as percentage of BW. The interaction between breed and day relative to calving tended $(P=0.10)$ to be associated with DMI (expressed as percentage of BW). ${ }^{*}$ Within-day-relative-to-calving means differ $(P<0.05)$; †within-day-relative-to-calving means tended to differ $(P<0.10)$. 
A

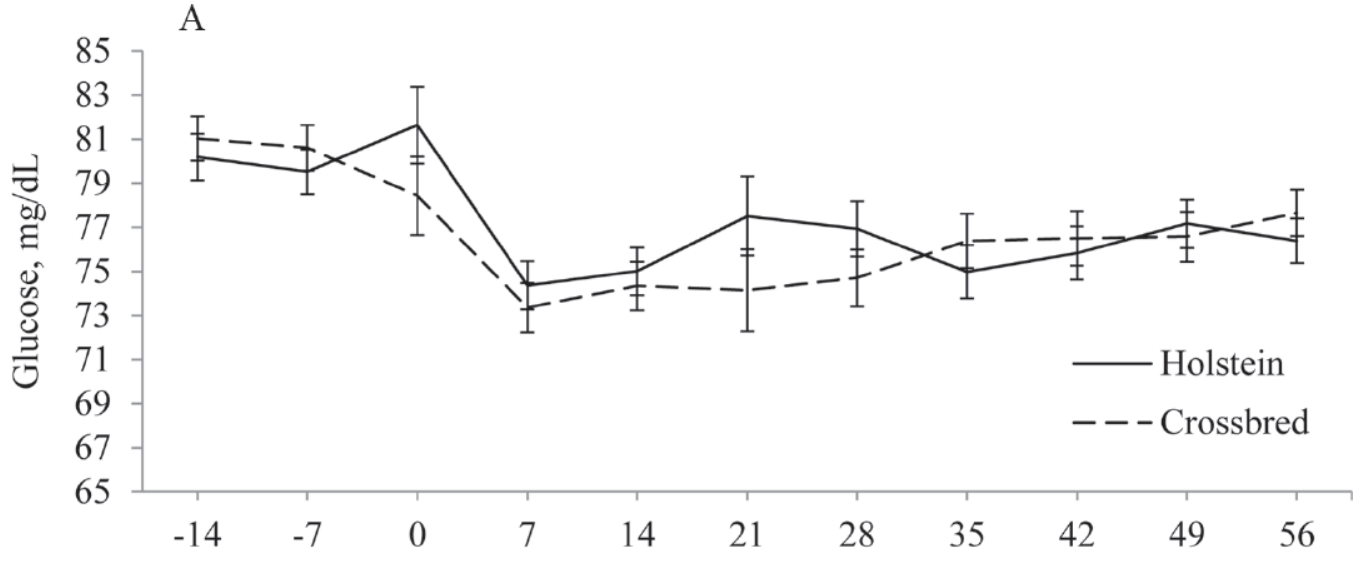

B
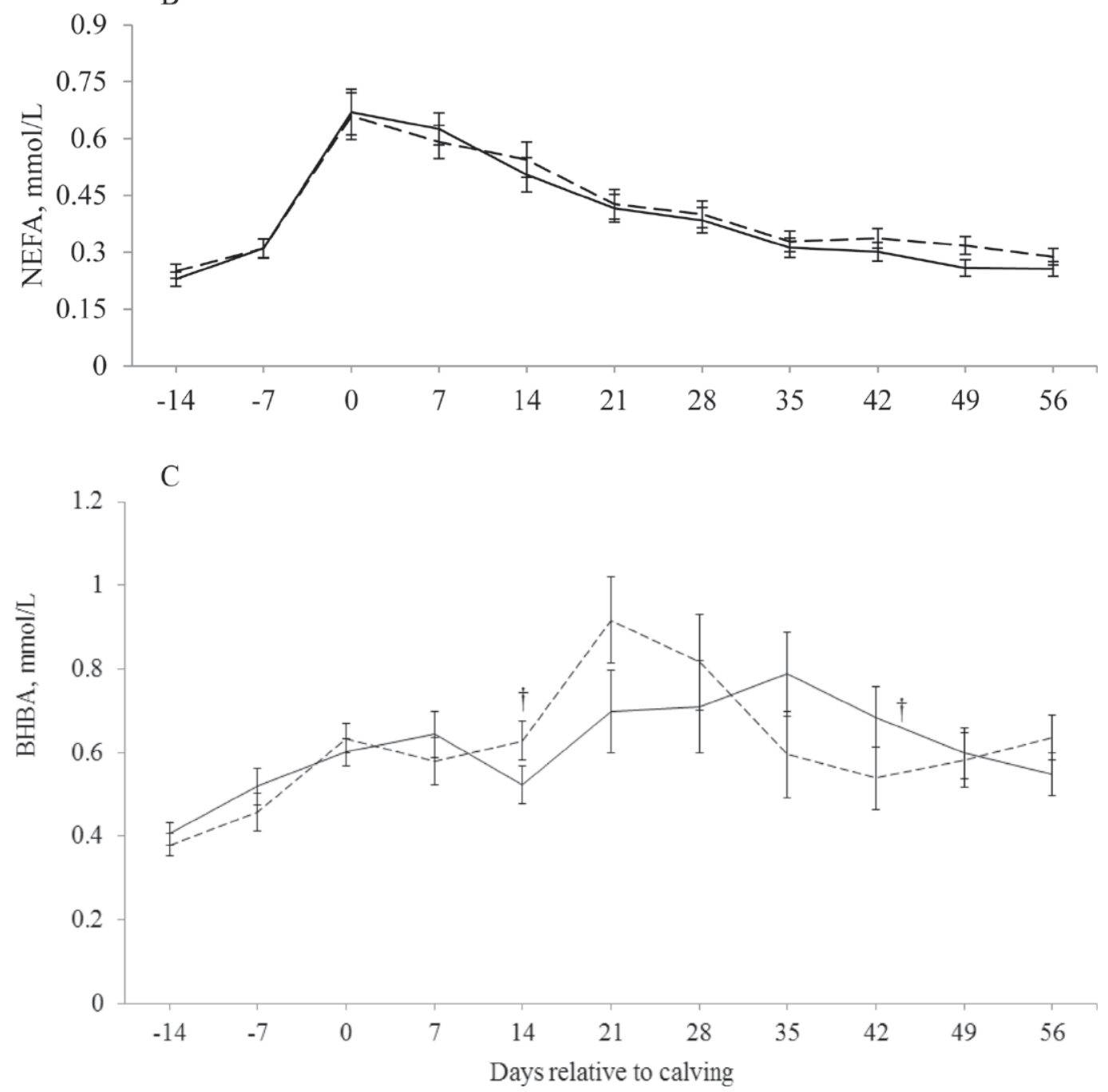

Figure 3. Association among breed and metabolic parameters. (A) Association between breed and glucose concentration. Breed was not associated with glucose concentration $(P=0.54)$. Day relative to calving $(P<0.01)$ and the interaction between breed and day relative to calving $(P<0.01)$, however, were associated with glucose concentration. (B) Association between breed and NEFA concentration. Breed $(P=0.56)$ and the interaction between breed and day relative to calving $(P=0.93)$ were not associated with NEFA concentration, but day relative to calving was associated with NEFA concentration $(P<0.01)$. (C) Association between breed and BHBA concentration. Breed was not associated with BHBA concentration $(P=0.95)$, but day relative to calving $(P<0.01)$ and the interaction between breed and day relative to calving $(P<0.01)$ were associated with BHBA concentration. †Within-day-relative-to-calving means differ $(P<0.10)$. Error bars represent SEM. 


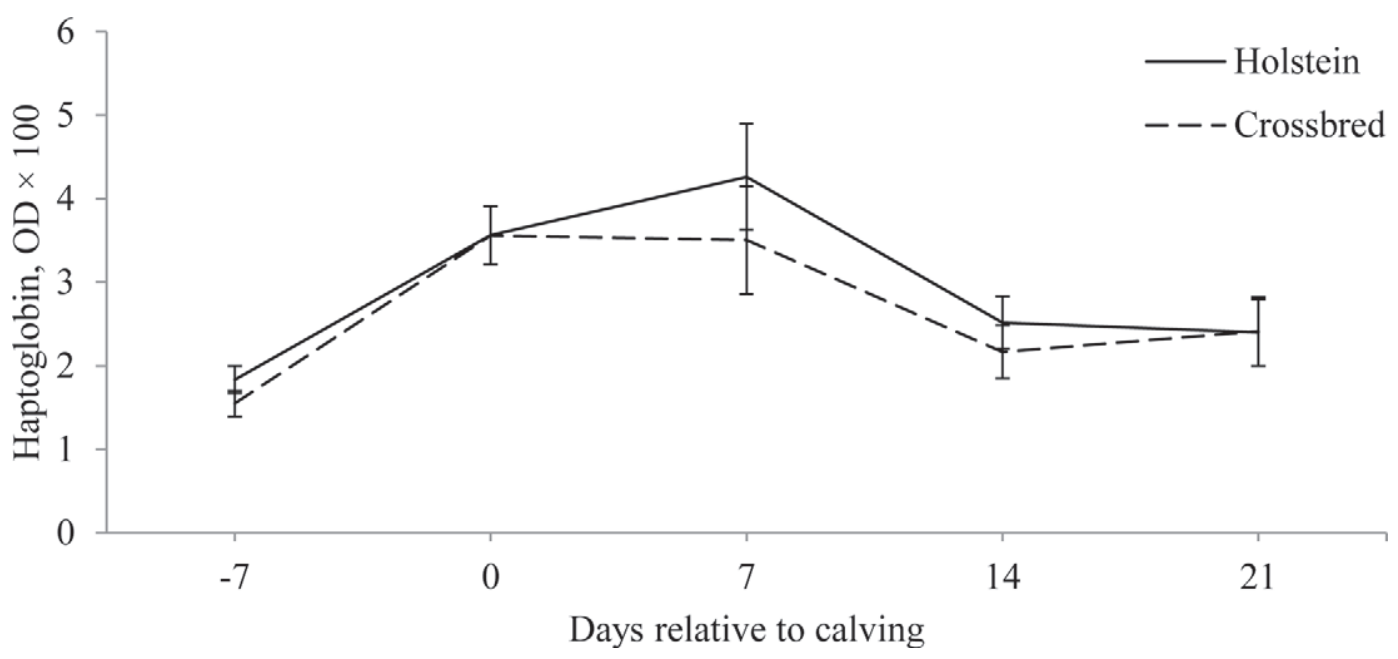

Figure 4. Concentrations of haptoglobin from -7 to $21 \mathrm{~d}$ relative to calving according to breed. Breed $(P=0.40)$ and the interaction between breed and day relative to calving $(P=0.85)$ were not associated with haptoglobin concentration. OD $=$ optical density. Error bars represent SEM.

0.71) were observed in milk yield of multiparous $\mathrm{HO}$ $(43.2 \pm 1.5 \mathrm{~kg} / \mathrm{d})$ and crossbred cows $(42.6 \pm 1.4 \mathrm{~kg} / \mathrm{d})$.

Breed was not associated $(P=0.41)$ with milk fat content, but $\mathrm{HO}$ cows had reduced milk protein content $(P<0.01)$ compared with MO-sired crossbred cows (Table 3$)$. Milk fat $(P=0.81)$ and protein $(P=0.74)$ yield were not associated with breed (Table 3 ). The interaction between breed and day relative to calving was associated $(P<0.01)$ with milk protein yield because on the first test, HO cows had reduced protein yield $(P$ $=0.04)$ compared with crossbred cows $(1.15 \pm 0.05$ vs.
$1.26 \pm 0.04 \mathrm{~kg} / \mathrm{d})$, but on the second $(P=0.85)$ and third $(P=0.15)$ tests no differences in milk protein yield were observed.

\section{DISCUSSION}

The objectives of the current experiment were to evaluate concentrations of metabolites and haptoglobin peripartum, uterine health and involution, and ovarian follicle growth and resumption of ovarian cyclicity after parturition of purebred $\mathrm{HO}$ and MO-sired cross-

Table 2. Calving and postpartum health parameters in Holstein and Montbéliarde (MO)-sired crossbred dairy cows

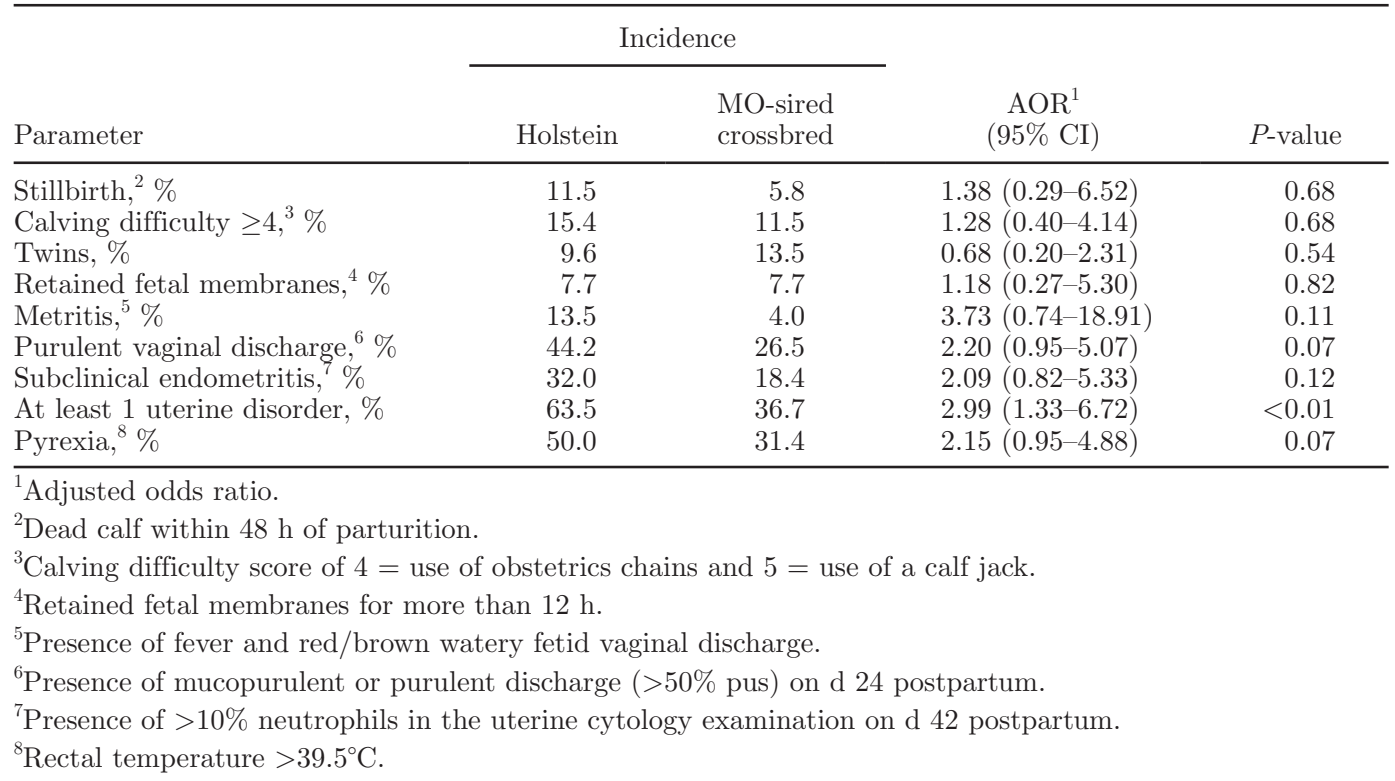




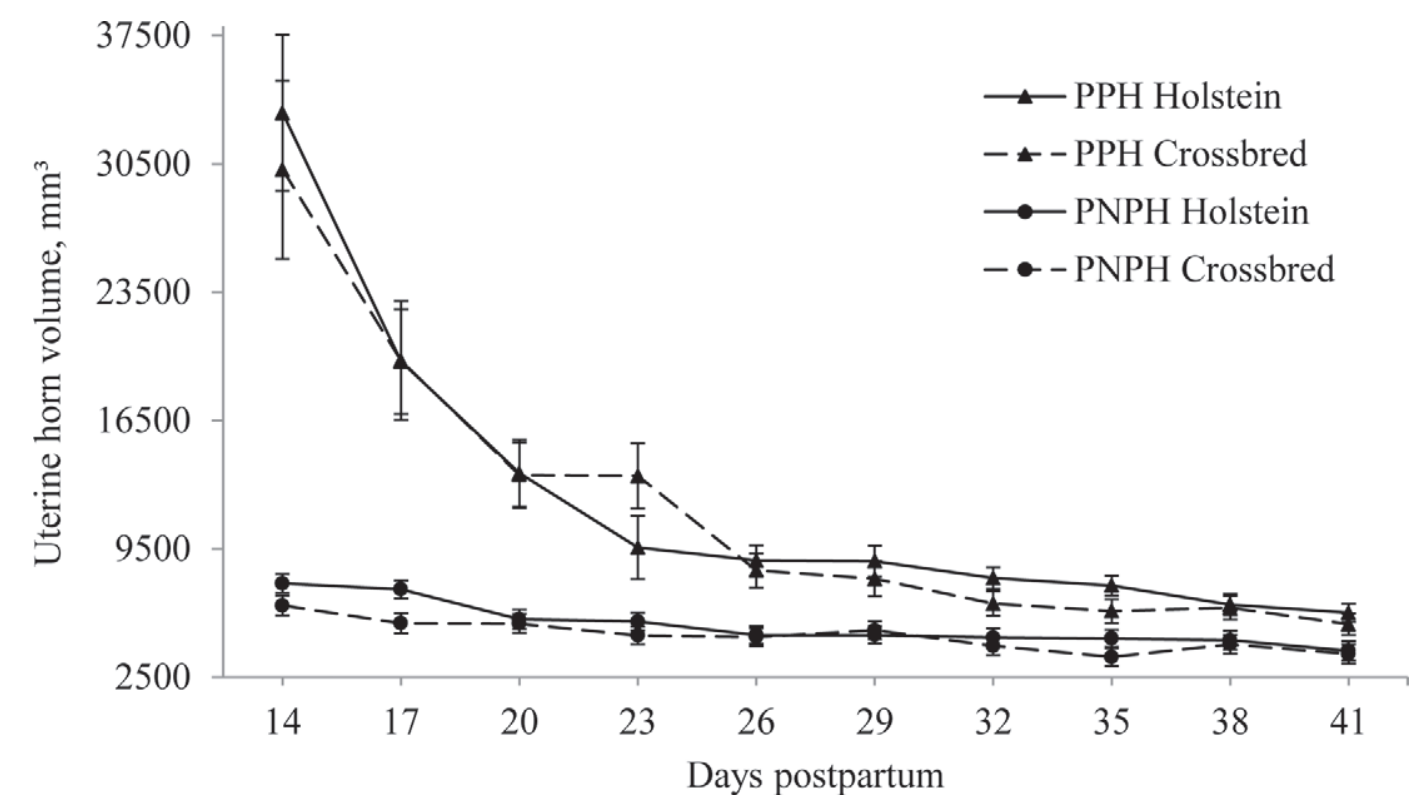

Figure 5. Association between breed and volume of previously pregnant uterine horn (PPH) and previously nonpregnant uterine horn (PNPH). Breed $(P=0.73)$ and the interaction between breed and day relative to calving $(P=0.48)$ were not associated with volume of PPH. Similarly, breed $(P=0.15)$ and the interaction between breed and day relative to calving $(P=0.45)$ were not associated with volume of the PNPH. Error bars represent SEM.

bred cows. The lack of differences in NEFA and BHBA concentrations, yield of ECM, and BW suggests that the energy status of $\mathrm{HO}$ and crossbred cows was not different during the experiment. Walsh et al. (2008) reported that $\mathrm{BW}$ of $\mathrm{HO}$ and $\mathrm{MO}-\mathrm{HO}$ crossbred cows were not different from wk 2 to 44 of lactation. Olson et al. (2011), on the other hand, demonstrated that firstlactation Jersey cows had more negative energy balance from 3 to 36 wk of lactation than HO cows, whereas HO $\times$ Jersey and Jersey $\times$ HO crossbred cows had intermediate energy balance during this period. Mendonça et al. (2013) demonstrated that HO cows had greater growth hormone concentration from $7 \mathrm{~d}$ before calving to $56 \mathrm{~d}$ after calving than MO-sired crossbred cows. This is a relevant observation because increased growth hormone during the early postpartum period is associated with a catabolic state that is often associated with lipolysis and increased NEFA concentrations (Burton

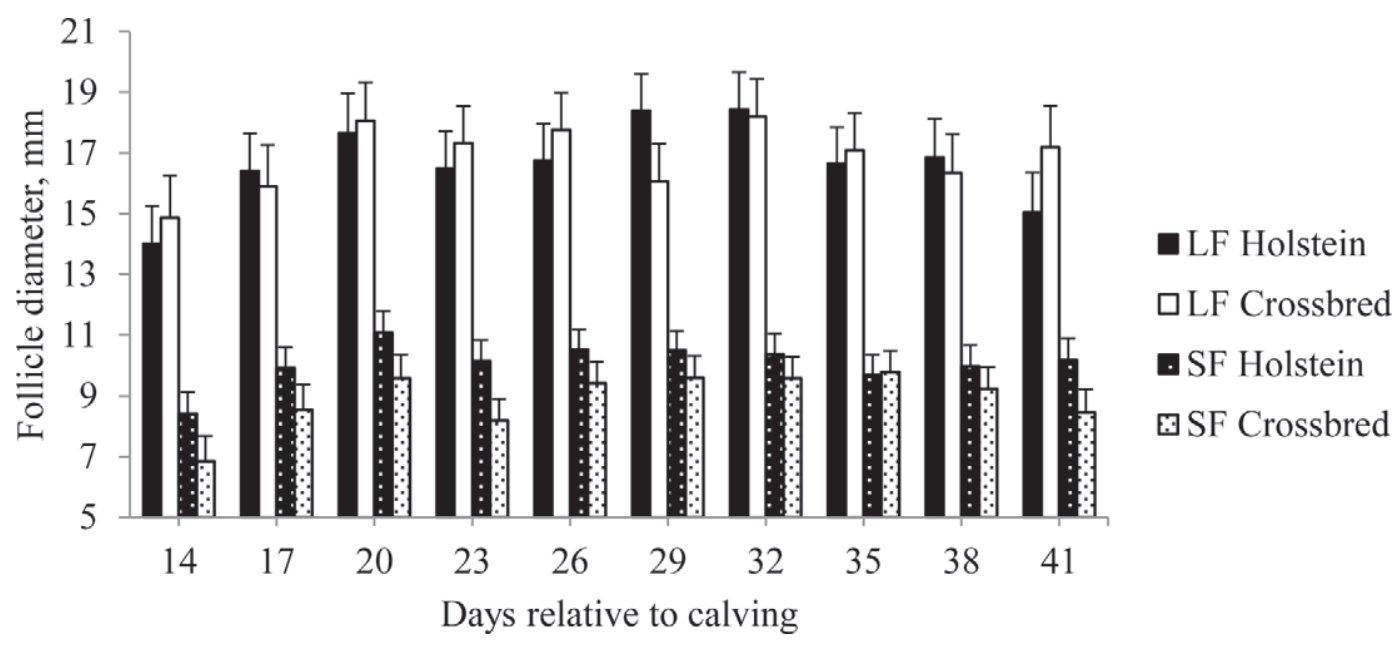

Figure 6. Association between breed and diameter of the largest follicle (LF) and subordinate follicle (SF). Breed $(P=0.85)$ and the interaction between breed and day relative to calving $(P=0.44)$ were not associated with the diameter of the largest follicle. Diameters of subordinate follicles of Holstein cows were larger compared with Montbéliarde-sired crossbred cows $(P=0.03)$. The interaction between breed and day relative to calving, however, was not associated with diameter of the subordinate follicle $(P=0.90)$. Error bars represent SEM. 

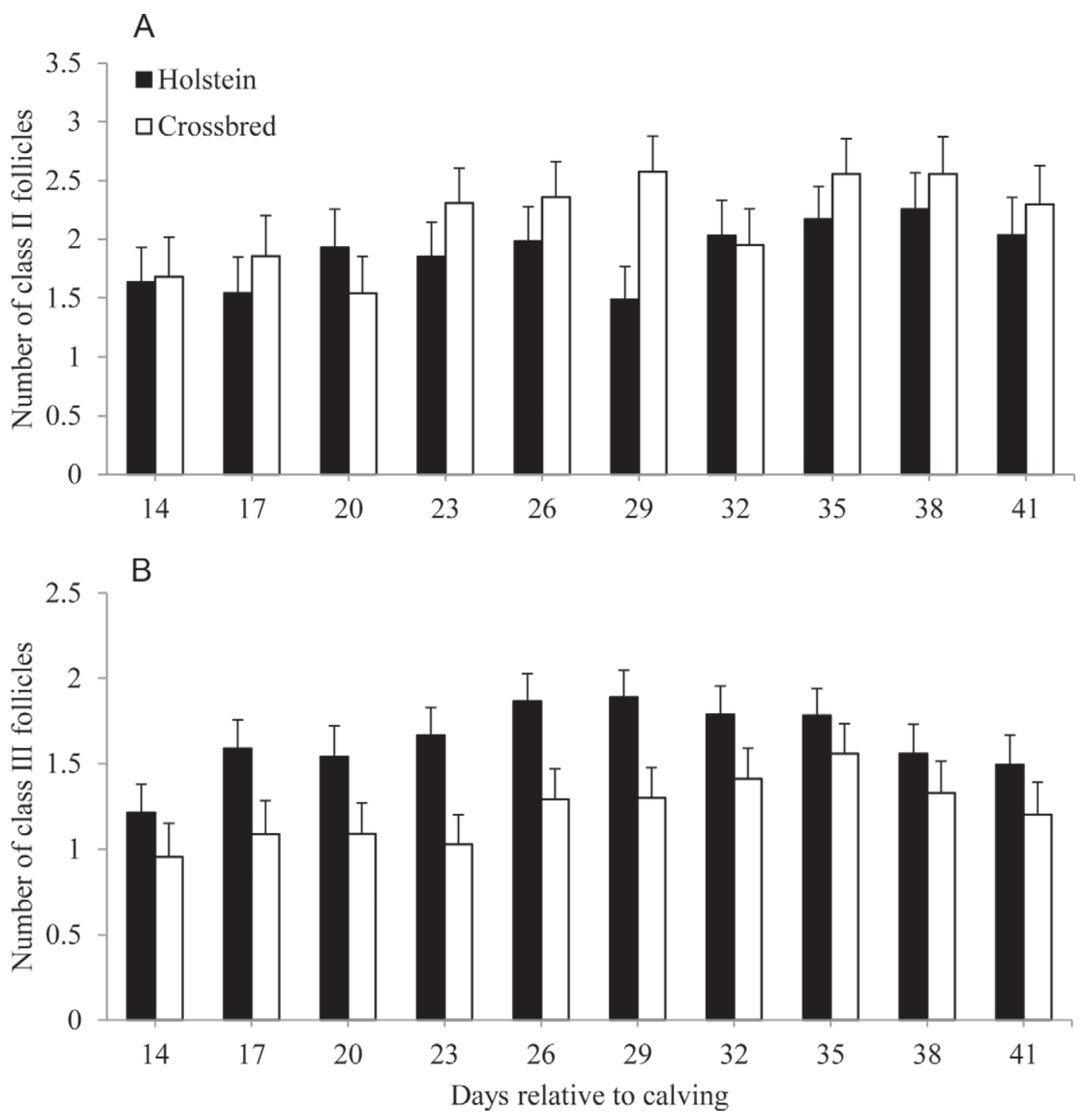

Figure 7. Association between breed and number of class II ( 5 to $9 \mathrm{~mm}$ ) and class III ( $\geq 10 \mathrm{~mm}$ ) follicles. (A) Number of class II follicles. Breed $(P=0.17)$ and the interaction between breed and day relative to calving $(P=0.51)$ were not associated with the number of class II follicles. (B) Number of class III follicles. Holstein cows had greater number of class III follicles than Montbéliarde-sired crossbred cows $(P<$ $0.01)$, but the interaction between breed and day relative to calving was not associated with the number of class III follicles $(P=0.79)$. Error bars represent SEM.

et al., 1994). It is possible, therefore, that the greater DMI during the peripartum period among HO cows compensated for increased growth hormone concentration and increased milk yield, preventing differences in NEFA concentrations between $\mathrm{HO}$ and crossbred cows. In the current experiment, the BCS of $\mathrm{HO}$ cows was reduced compared with MO-sired crossbred cows, which is supported by the theory that energy partitioning is determined in part by genetics (Veerkamp et al., 2003). Thus, reduced BCS of $\mathrm{HO}$ cows likely reflects genetic selection of the HO breed for milk yield and angularity and greater BCS of MO-sired crossbred cows may reflect genetic selection of the MO breed for milk yield and body condition.
Holstein cows tended to be more likely to be diagnosed with purulent vaginal discharge and were more likely to be diagnosed with at least 1 uterine disease than MO-sired crossbred cows. Peripheral PMNL from HO cows had lower phagocytic activity on the day of calving than $7 \mathrm{~d}$ before calving, whereas phagocytic activity of PMNL from MO-sired crossbred cows did not change in the last $7 \mathrm{~d}$ of gestation (Mendonça et al., 2013). Polymorphonuclear neutrophilic leukocytes from HO cows also had reduced expression of CD18 (an adhesion molecule) from $7 \mathrm{~d}$ before calving to $21 \mathrm{~d}$ after calving compared with crossbred cows (Mendonça et al., 2013). In recent years, reduced prepartum feed intake has been demonstrated to be a critical predis- 
Table 3. Milk production and composition of Holstein and Montbéliarde (MO)-sired crossbred dairy primiparous and multiparous cows

\begin{tabular}{lccrrr}
\hline & & \multicolumn{3}{c}{$P$-value } \\
\cline { 4 - 6 } & & & & & BO-sired \\
Variable & Holstein & & Breed & Parity & $\begin{array}{c}\text { Breed } \\
\times \text { parity }\end{array}$ \\
\hline Milk yield, kg/d & $42.3 \pm 1.9$ & $38.8 \pm 2.2$ & 0.05 & 0.05 & 0.10 \\
Fat, \% & $3.8 \pm 0.08$ & $3.9 \pm 0.08$ & 0.41 & 0.40 & 0.45 \\
Fat yield, kg/d & $1.5 \pm 0.05$ & $1.4 \pm 0.05$ & 0.81 & 0.02 & 0.38 \\
Protein, \% & $3.0 \pm 0.04$ & $3.1 \pm 0.04$ & $<0.01$ & 0.10 & 0.12 \\
Protein yield, kg/d & $1.3 \pm 0.04$ & $1.3 \pm 0.03$ & 0.74 & 0.13 & 0.14 \\
ECM yield, $\mathrm{kg} / \mathrm{d}$ & $39.6 \pm 1.1$ & $39.1 \pm 1.2$ & 0.72 & $<0.01$ & 0.22 \\
Log SCC & $2.7 \pm 0.2$ & $2.5 \pm 0.2$ & 0.61 & 0.71 & 0.17 \\
\hline
\end{tabular}

posing factor for metritis (Huzzey et al., 2007) because of increased NEFA concentrations and compromised neutrophil function during the peripartum (Hammon et al., 2006). It is difficult to explain differences in PMNL activity based on differences in DMI in the peripartum period, because no differences in metabolic parameters between breeds were observed. Therefore, the importance of breed complementarity or heterosis, or both, for improved health of MO-sired crossbred cows should not be overlooked. Heterosis is observed as improved performance or health of crossbred animals compared with their parental average because increased heterozygosity alleviates inbreeding depression (VanRaden and Sanders, 2003). In a large retrospective experiment, Snowder et al. (2005) demonstrated that crossbred beef calves had reduced incidence of bovine respiratory disease compared with purebred beef calves. It is also possible that the MO breed is more resistant to peripartum uterine diseases, making MO-sired crossbred cows less likely to develop uterine diseases than purebred $\mathrm{HO}$ cows. Montbéliarde cows and MO-sired crossbred cows had reduced SCS (Koç, 2011) and were less likely to be removed from the herd (Heins et al., 2012), respectively, compared with purebred cows. Holstein $\times$ Jersey and Jersey $\times$ HO crossbred cows were less likely to have metritis than purebred HO cows (Olson et al., 2011). The number of cows enrolled in the current experiment may have been too small to detect differences in incidences of metritis and subclinical endometritis. More experiments are warranted, therefore, to determine differences in incidences of uterine diseases of purebred $\mathrm{HO}$ and crossbred cows.

Even though the incidence of subclinical endometritis at 42 DIM did not differ between $\mathrm{HO}$ and MO-sired crossbred cows, MO-sired crossbred cows positive for subclinical endometritis had a greater percent-

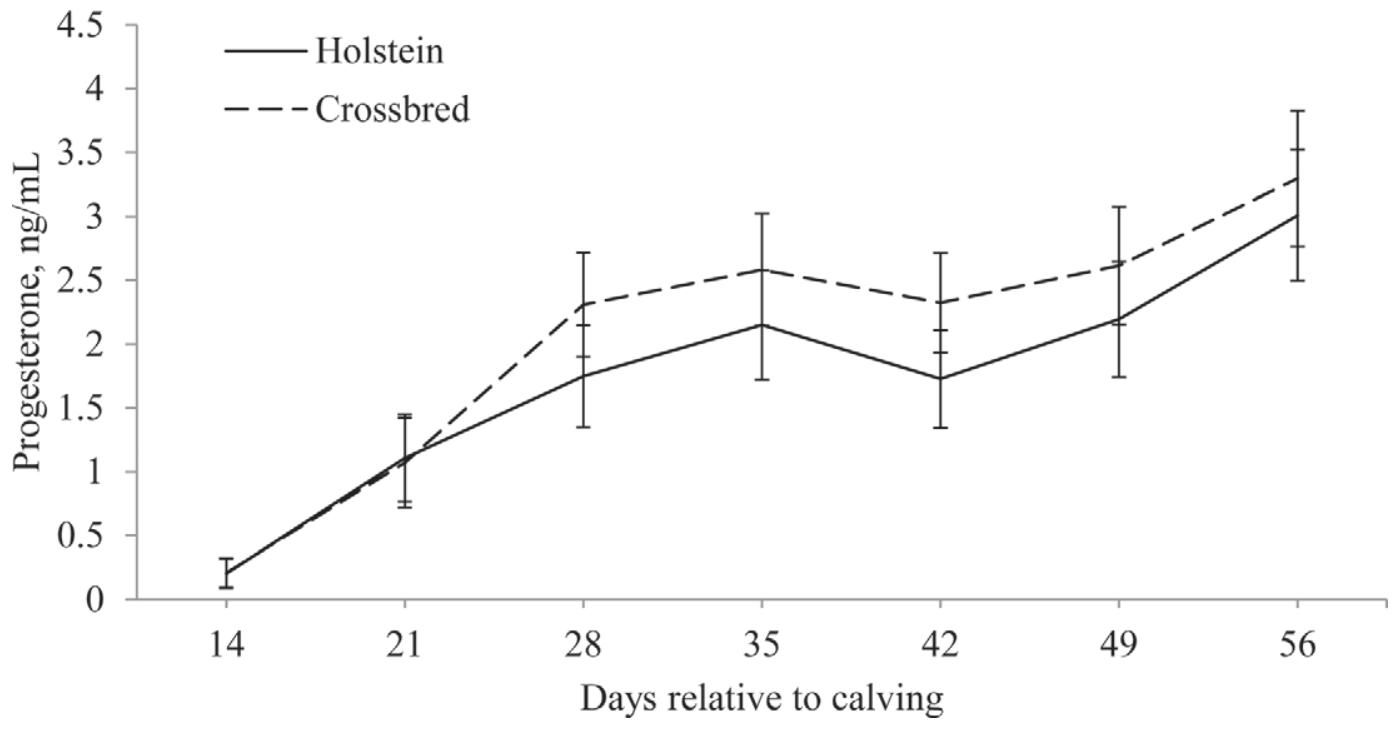

Figure 8. Progesterone concentration of Holstein and Montbéliarde-sired crossbred cows from d 14 to 56 postpartum. Breed $(P=0.24)$ and the interaction between breed and day relative to calving $(P=0.88)$ were not associated with progesterone concentration, but day relative to calving was associated with progesterone concentration $(P<0.01)$. Error bars represent SEM. 
age of PMNL in the uterine cytology than HO cows positive for subclinical endometritis. In a companion manuscript, Mendonça et al. (2013) demonstrated no differences in peripheral PMNL expression of adhesion molecules or function between crossbred and purebred HO cows at 42 DIM. Thus, it is unclear why such difference in PMNL population in the uterus of cows with subclinical endometritis was observed.

In spite of the fact that HO cows had increased incidence of uterine disorders and greater rectal temperature from calving to 15 DIM, no differences were observed in haptoglobin concentration from $7 \mathrm{~d}$ before calving to 21 DIM between breeds. Haptoglobin is an acute-phase protein produced mainly in the liver that is generally elevated in metritic cows (Huzzey et al., 2009). It is possible that the numerical difference in percentage of cows diagnosed with metritis between breeds was not large enough to produce differences in haptoglobin concentration.

Even though $\mathrm{HO}$ cows had greater incidence of uterine disorders compared with MO-sired crossbred cows, no difference was observed in uterine involution postpartum. On the other hand, dynamics of ovarian structure differed between breeds. The diameter of the subordinate follicle and the number of class III follicles present in the ovaries of $\mathrm{HO}$ cows were greater than MO-sired crossbred cows. These ovarian characteristics are typical of cows with follicle codominance. Holstein cows had greater concentrations of cortisol than MOsired crossbred cows $(\mathrm{HO}=9.45 \pm 0.82$ vs. MO-sired crossbred $=7.10 \pm 0.77 \mathrm{ng} / \mathrm{mL}$; Mendonça et al., 2013) and increasing concentrations of ACTH and cortisol have been suggested to cause a decrease in LH secretion by the pituitary (Li and Wagner, 1983), which may lead to follicle codominance.

The speed at which the first CL was diagnosed by ultrasonography in $\mathrm{HO}$ cows was slower compared with MO-sired crossbred cows. Interestingly, breed was not associated with the speed at which cows were detected to have progesterone concentration $\geq 1 \mathrm{ng} / \mathrm{mL}$. Such difference is likely to be a consequence of sampling schedule because blood samples were collected once weekly, whereas ultrasound exams were performed at 3 -d intervals. The slower rate of diagnosis of the first $\mathrm{CL}$ in $\mathrm{HO}$ cows may be associated with greater concentrations of cortisol in $\mathrm{HO}$ cows compared with crossbred cows (Li and Wagner, 1983). The slower rate of diagnosis of the first CL in HO cows cannot be explained by breed differences in plasma concentration of IGF-I, a key hormone involved in resumption of cyclicity postpartum (Butler, 2000), because no differences were detected in IGF-I concentrations from $7 \mathrm{~d}$ before calving to 56 DIM between HO and MO-sired crossbred cows (Mendonça at al., 2013).
Holstein cows had greater milk yield than crossbred cows during the first 90 DIM. Energy-corrected milk yield in the first 90 DIM was not different between breeds because MO-sired cows had greater milk protein content. First-lactation HO cows have been reported to have greater milk yield and greater fat-plus-protein yield compared with first-lactation $\mathrm{MO}-\mathrm{HO}$ crossbred cows (Heins et al., 2006). Walsh et al. (2008) observed no difference in total yield of SCM between HO and MO-sired crossbred cows. The data regarding milk yield, milk components, and ECM yield should be interpreted with caution because cows were tested once monthly and the range of DIM at first, second, and third tests were 5 to 34,35 to 64 , and 65 to 94 DIM, respectively. Furthermore, the aim of the current experiment was not to compare productive parameters of crossbred and $\mathrm{HO}$ cows, but the lack of difference in ECM yield in the first 90 DIM between breeds may suggest that energy requirements for ECM production were not different for $\mathrm{HO}$ and $\mathrm{MO}$-sired crossbred cows.

Holstein cows tended to have greater DMI than crossbred cows from 6 wk before to 6 wk after calving. The tendency of HO cows to have greater DMI may be associated with their greater milk yield during the first 90 DIM compared with MO-sired crossbred cows, which may have led to HO cows diverting more ingested nutrients to the production of lactose and milk. Frame size may affect physical capacity for feed intake and the lack of difference in BW between breeds is likely to result in more equitable comparison of DMI between breeds. Dry matter intake of HO cows, however, decreased from 1.9 to $1.4 \%$ of BW from 15 to $1 \mathrm{~d}$ before calving, whereas DMI of crossbred cows was 1.5 and $1.4 \%$ of $\mathrm{BW}$ on $\mathrm{d} 15$ and 1 before calving, respectively. Dry matter intake and the magnitude of decrease in DMI in the last weeks of gestation are critical for health and performance (Drackley, 1999; LeBlanc, 2010). Zamet et al. (1979) described that DMI of cows with at least 1 peripartum disorder decreased from 1.8 to $0.9 \%$ of BW during the last $27 \mathrm{~d}$ of gestation, whereas healthy cows had a smaller decrease in DMI of BW (from 1.8 to $1.2 \%$ ). Huzzey et al. (2007) demonstrated that cows with severe metritis had reduced DMI as early as 2 wk before calving compared with healthy cows. Because no differences existed between breeds regarding NEFA and BHBA concentrations, it is difficult to explain differences in uterine health based on prepartum changes in DMI. In the current experiment, DMI expressed as a percentage of BW was based on only 1 measurement of BW (14 d before calving), which may have caused variations in gut fill and calf weight to influence this outcome. Therefore, the tendency for differences in DMI expressed as percentage of BW should be taken with caution, but indicates that more research 
is needed to determine differences between breeds in DMI peripartum and possible causes of disparities.

\section{CONCLUSIONS}

The reduced incidence of postpartum uterine disorders in crossbred cows is likely to be a consequence of breed complementarity or hybrid vigor because metabolic parameters were not different between breeds. Considering the importance of uterine disorders for reproductive and productive performances, dairy producers may reduce the incidence of postpartum diseases by crossing $\mathrm{HO}$ cows with bulls of other dairy breeds. Future experiments should focus on determining why peripartum DMI of $\mathrm{HO}$ and crossbred cows were different, but no differences in concentrations of metabolites between breeds were observed.

\section{ACKNOWLEDGMENTS}

The authors thank James Linn and the University of Minnesota (St. Paul) dairy barn staff.

\section{REFERENCES}

Ballou, M. A., R. C. Gomes, S. O. Juchem, and E. J. DePeters. 2009. Effects of dietary supplemental fish oil during the peripartum period on blood metabolites and hepatic fatty acid compositions and total triacylglycerol concentrations of multiparous Holstein cows. J. Dairy Sci. 92:657-669.

Burton, J. L., B. W. McBride, E. Block, D. R. Glimm, and J. J. Kennelly. 1994. A review of bovine growth hormone. Can. J. Anim. Sci. 74:167-201.

Butler, W. R. 2000. Nutritional interactions with reproductive performance in dairy cattle. Anim. Reprod. Sci. 60-61:449-457.

Charlesworth, D., and J. H. Willis. 2009. The genetics of inbreeding depression. Nat. Rev. Genet. 10:783-796.

Cole, L. J., and I. Johansson. 1948. Inheritance in crosses of Jersey and Holstein-Friesian with Aberdeen-Angus cattle. III. Growth and body type, milk yield and butterfat percentage. Am. Nat. $82: 265-280$.

Drackley, J. K. 1999. ADSA Foundation Scholar Award. Biology of dairy cows during the transition period: The final frontier? J. Dairy Sci. 82:2259-2273.

Falconer, D. S., and T. F. C. Mackay. 1996. Introduction to quantitative genetics. 4th ed. Longman, Essex, UK.

Ferguson, J. D., D. T. Galligan, and N. Thomsen. 1994. Principal descriptors of body condition score in HO cows. J. Dairy Sci. 77:2695-2703.

Goff, J. P., and R. L. Horst. 1997. Physiological changes at parturition and their relationship to metabolic disorders. J. Dairy Sci. 80:1260-1268.

Grummer, R. R., D. G. Mashek, and A. Hayirli. 2004. Dry matter intake and energy balance in the transition period. Vet. Clin. North Am. Food Anim. Pract. 20:447-470.

Hammon, D. S., I. M. Evjen, T. R. Dhiman, J. P. Goff, and J. L. Walters. 2006. Neutrophil function and energy status in Holstein cows with uterine health disorders. Vet. Immunol. Immunopathol. 113:21-29.

Heins, B. J., L. B. Hansen, and A. De Vries. 2012. Survival, lifetime production, and profitability of Normande $\times$ Holstein, Montbéliarde $\times$ Holstein, and Scandinavian Red $\times$ Holstein crossbreds versus pure Holsteins. J. Dairy Sci. 95:1011-1021.
Heins, B. J., L. B. Hansen, and A. J. Seykora. 2006. Production of pure Holsteins versus crossbreds of Holstein with Normande, Montbeliarde, and Scandinavian Red. J. Dairy Sci. 89:2799-2804.

Hulbert, L. E., C. J. Cobb, J. A. Carroll, and M. A. Ballou. 2011. Effects of changing milk replacer feedings from twice to once daily on Holstein calf innate immune responses before and after weaning. J. Dairy Sci. 94:2557-2565.

Huzzey, J. M., T. F. Duffield, S. J. LeBlanc, D. M. Veira, D. M. Weary, and M. A. von Keyserlingk. 2009. Short communication: Haptoglobin as an early indicator of metritis. J. Dairy Sci. 92:621-625.

Huzzey, J. M., D. M. Veira, D. M. Weary, and M. A. von Keyserlingk. 2007. Prepartum behavior and dry matter intake identify dairy cows at risk for metritis. J. Dairy Sci. 90:3220-3233.

Kasimanickam, R., T. F. Duffield, R. A. Foster, C. J. Gartley, K. E. Leslie, J. S. Walton, and W. H. Johnson. 2004. Endometrial cytology and ultrasonography for the detection of subclinical endometritis in postpartum dairy cows. Theriogenology 62:9-23.

Koç, A. 2011. A study of the reproductive performance, milk yield, milk constituents, and somatic cell count of Holstein-Friesian and Montbeliarde cows. Turk. J. Vet. Anim. Sci. 35:295-302.

LeBlanc, S. 2010. Monitoring metabolic health of dairy cattle in the transition period. J. Reprod. Dev. 56(Suppl.):S29-S35.

Li, P. S., and W. C. Wagner. 1983. In vivo and in vitro studies on the effect of adrenocorticotropic hormone or cortisol on the pituitary response to gonadotropin releasing hormone. Biol. Reprod. 29:25-37.

Mendonca, L. G. D., N. B. Litherland, M. C. Lucy, D. H. Keisler, M A. Ballou, L. B. Hansen, and R. C. Chebel. 2013. Comparison of innate immune responses and somatotropic axis components of Holstein and Montbéliarde-sired crossbred dairy cows during the transition period. J. Dairy Sci. 96:3588-3598.

NAHMS (National Animal Health Monitoring System). 2007. Dairy 2007, Part I: Reference of dairy cattle health and management practices in the United States, 2007. US Department of Agriculture:Animal and Plant Health Inspection Service:Veterinary Services:Centers for Epidemiology and Animal Health (USDA:APHIS:VS:CEAH), NAHMS, Fort Collins, CO.

Olson, K. M., B. G. Cassell, M. D. Hanigan, and R. E. Pearson. 2011. Short communication: Interaction of energy balance, feed efficiency, early lactation health events, and fertility in first-lactation Holstein, Jersey, and reciprocal F1 crossbred cows. J. Dairy Sci. 94:507-511.

Palmquist, D. L. 1972. Palmitic acid as a source of endogenous acetate and $\beta$-hydroxybutyrate in fed and fasted ruminants. J. Nutr. 102:1401-1406.

Snowder, G. D., L. D. Van Vleck, L. V. Cundiff, and G. L. Bennett. 2005. Influence of breed, heterozygosity, and disease incidence on estimates of variance components of respiratory disease in preweaned beef calves. J. Anim. Sci. 83:1247-1261.

Tyrrell, H. F., and J. T. Reid. 1965. Prediction of the energy value of cow's milk. J. Dairy Sci. 48:1215-1223.

VanRaden, P. M., and A. H. Sanders. 2003. Economic merit of crossbred and purebred US dairy cattle. J. Dairy Sci. 86:1036-1044.

Veerkamp, R. F., B. Beerda, and T. van der Lende. 2003. Effects of genetic selection for milk yield on energy balance, levels of hormones, and metabolites in lactating cattle, and possible links to reduced fertility. Livest. Prod. Sci. 83:257-275.

Walsh, S., F. Buckley, K. Pierce, N. Byrne, J. Patton, and P. Dillon. 2008. Effects of breed and feeding system on milk production, body weight, body condition score, reproductive performance, and postpartum ovarian function. J. Dairy Sci. 91:4401-4413.

Wriedt, C. 1930. The inheritance of butter-fat percentage in crosses of Jersey with red Danes. J. Genet. 22:45-63.

Young, C. W., and A. J. Seykora. 1996. Estimates of inbreeding and relationship among registered Holstein females in the United States. J. Dairy Sci. 79:502-505.

Zamet, C. N., V. F. Colenbrander, R. E. Erb, C. J. Callahan, B. P. Chew, and N. J. Moeller. 1979. Variables associated with peripartum traits in dairy cows. II. Interrelationships among disorders and their effects on intake of feed and on reproductive efficiency. Theriogenology 11:245-260. 